
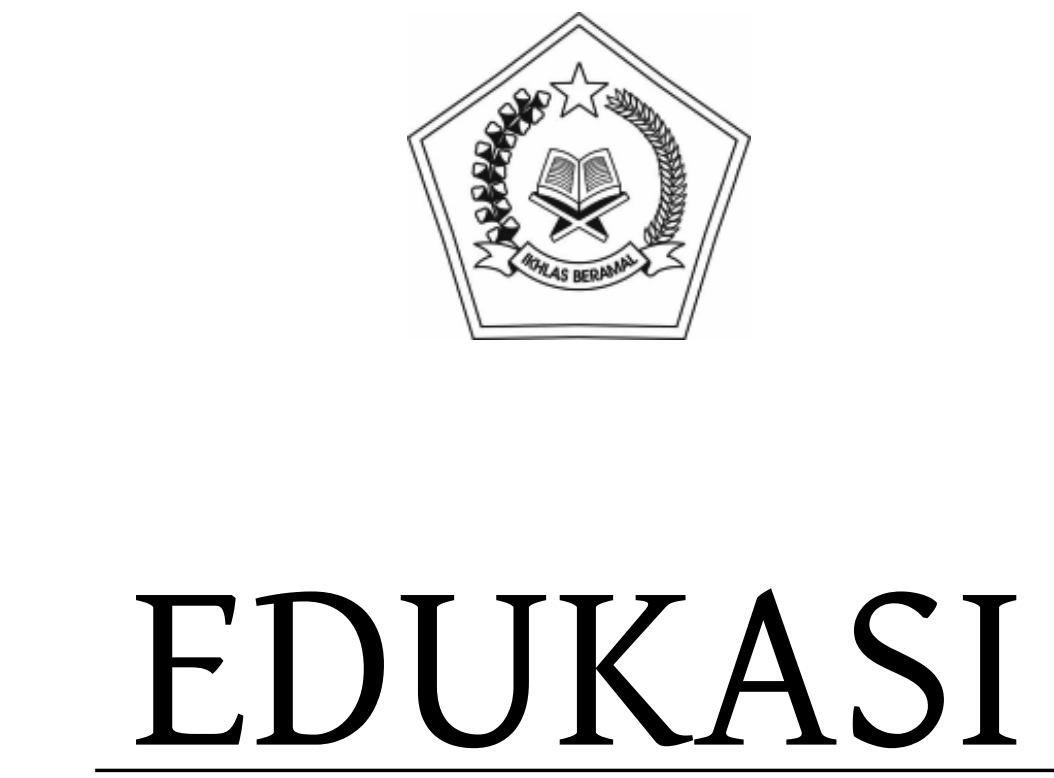

JURNAL PENELITIAN PENDIDIKAN AGAMA DAN KEAGAMAAN

VOLUME 13, NOMOR 3, DESEMBER 2015 


\title{
LITERATUR KEAGAMAAN AKTIVIS ROHANI ISLAM DI SEKOLAH MENENGAH ATAS (SMA) \\ Studi Kasus di Kota Serang Propinsi Banten
}

\author{
RELIGIOUS LITERATURE OF RELIGIOUS \\ ACTIVIST AT SENIOR HIGH SCHOOL \\ Case Study in Serang City of Banten Province
}

\author{
Agus Iswanto \\ Peneliti Balai Penelitian dan Pengembangan Agama Jakarta \\ Jl. Rawa Kuning No. 6 Pulo Gebang Cakung Jakarta Timur \\ Email: agus.iswanto83@gmail.com
}

Naskah diterima 9 Sepetember 2015, direvisi 8 Desember 2015, disetujui 15 Desember 2015

\begin{abstract}
This writing presents a research outcome on religious literature of the religious activist at Senior High School (SMA). It aims at explaining student's reading model towards selected religious readings and identifying affiliation of the understanding on the religious literature. The research is performed by using a textual reception theory which the data is collected through interview and study on the text. This research concludes that students perform a negotiation model reading. The negotiation is carried out in terms of language style. A substance or message with any idea will be interested for them if it is presented by an exciting language style. Meanwhile, there are two styles in the religious literature affiliation, namely moderate style meaning that it corresponds to a mainstream of religious perspective in Indonesia, and another one is based on khilafah ideas that affiliate to a transnational Islamic movement. The second affiliation is more interesting for them since the style is created in an interesting way.
\end{abstract}

Keyword: Religious literature, religious education, extracurricular education

\section{Abstrak}

Tulisan ini menyajikan hasil penelitian tentang literatur keagamaan aktivis Rohani Islam di Sekolah Menengah Atas (SMA). Tujuannya adalah menjelaskan model pembacaan siswa terhadap bacaan keagamaan yang dipilih, dan mengidentifikasi afiliasi pemahaman keagamaan literatur tersebut. Penelitian dilakukan dengan menggunakan teori resepsi teks, yang datadatanya dikumpulkan melalui wawancara dan telaah teks. Penelitian ini menyimpulkan bahwa siswa-siswi melakukan pembacaan model negosiasi. Negosiasi terjadi dalam hal gaya bahasa. Substansi atau pesan dengan ide-ide apapun akan disenangi jika disajikan dengan gaya bahasa yang menarik bagi mereka. Adapun afiliasi literatur keagamaannya ada yang berhaluan moderat dalam arti sesuai dengan arus utama pandangan keislaman di Indonesia, dan ada yang berhaluan ide-ide khilafah yang berafiliasi dengan gerakan Islam transnasional. Afiliasi yang kedua ini yang lebih banyak diminati karena gaya yang menarik bagi mereka.

Kata kunci: Literatur keagamaan, buku agama, pendidikan agama, pendidikan ekstrakurikuler 


\section{PENDAHULUAN}

Pemahaman terhadap teks atau literatur yang berisi ajaran-ajaran agama dapat menentukan pembentukan sikap dan perilaku sosial, demikian yang diajukan oleh Weber ketika melihat pengaruh ideide keagamaan Kristen Protestan dalam perkembangan kapitalisme di Eropa. ${ }^{1}$ Dalam Islam, teks dan pemahaman atasnya juga menjadi bagian yang penting dalam sejarah perkembangan pemikiran Islam. Keduanya menjadi media penyebaran ideide yang diusung masing-masing pemikiran dan gerakan Islam tersebut. Meskipun dua sumber utama tekstual Islam adalah alQur'an dan Hadis, tetapi melalui aktivitas transmisi, interpretasi dan resepsi, ide-ide atau pemahaman terhadap dua sumber ajaran tersebut memunculkan produksiproduksi pemikiran-pemikiran lanjutan yang tertuang dalam teks-teks "turunan"nya sebagai tafsir atas dua sumber teks utama tersebut atau hanya langsung dipahami dan dipraktikan. ${ }^{2}$

Karena itu literatur keagamaan menjadi salah satu sumber pengetahuan agama, selain sumber lainnya, seperti ceramahceramah dan pendidikan keagamaan. ${ }^{3}$ Dalam konteks pendidikan, teks tetap digunakan sebagai salah satu sumber atau media belajar pengetahuan agama. Namun, kajian mengenai literatur keagamaan umumnya dilakukan dengan menggunakan pendekatan

1 Max Weber. 2001. The Protestant Ethic and the Spirit of Capitalism. Terbit pertama kali 1930. Diterjemahkan oleh Talcott Parsons. London: Routledge Classics, h. 102.

${ }^{2}$ Van der Voort, Nicolet Boekhoef, Kees Versteegh dan Joas Wagemakers. 2011. "Introduction." Dalam The Transmission and Dynamics of the Textual Sources of Islam. Ed. Van der Voort, Nicolet Boekhoef, Kees Versteegh dan Joas Wagemakers. Leiden and Boston: Brill, h. 1-2.

${ }^{3}$ Rudy Harisyah Alam dkk. 2007. Akses Literatur Keagamaan pada Masyarakat Muslim. Jakarta: Balai Litbang Agama Jakarta, h. 3. kajian teks atau mengkaji ketersediaan literatur keagamaan dalam lingkup suatu lembaga pendidikan tertentu, seperti yang dilakukan oleh van Bruinessen tentang kitab-kitab 'kuning' yang digunakan di pesantren-pesantren Indonesia, ${ }^{4}$ Puslitbang Lektur dan Khazanah Kegaaman Badan Litbang dan Diklat Kementerian Agama yang melakukan kajian tentang pergeseran literatur keagamaan di sejumlah pondok pesantren salafiyah di Indonesia..$^{5}$ Sebuah penelitian yang lebih memfokuskan pada tingkat dan pola akses masyarakat terhadap informasi dan pengetahuan keagamaan yang tersedia dalam bentuk literatur keagamaan, telah dilakukan oleh Balai Litbang Agama Jakarta, ${ }^{6}$ namun belum secara khusus menyoroti literatur keagamaan di lembaga pendidikan atau sekolah.

Terkait dengan pendidikan keagamaan, sebuah survei tentang pengajaran kitab kuning di pondok pesantren telah dilakukan oleh Puslitbang Pendidikan Agama dan Keagamaan. ${ }^{7}$ Tujuan survei ini adalah memetakan nama-nama kitab kuning yang banyak diajarkan di pesantren, dan menggambarkan tingkatan pengajaran kitab kuning tersebut. Untuk lembaga pendidikan madrasah, pernah juga dilakukan penelitian tentang bacaan keagamaan yang diminati oleh siswa Madrasah Aliyah dan Madrasah

\footnotetext{
${ }^{4}$ Martin van Bruinessen. 1990. "Kitab Kuning; Books in Arabic script used in the Pesantren milieu; Comments on a new collection in the KITLV Library." Bijdragen tot de Taal-, Land-en Volkenkunde 146 $(2 / 3)$.

${ }^{5}$ Syatibi, M, Badri Yunardi, dkk. 2006. Pergeseran Literatur di Pondok Pesantren Salafiyah di Indonesia. Jakarta: Puslitbang Lektur Keagamaan.

${ }^{6}$ Rudy Harisyah Alam dkk. 2007. Ibid.

7 Husen Hasan Basri, dkk. 2011. Pengajaran Kitab Kuning di Pondok Pesantren. Jakarta: Puslitbang Pendidikan Agama dan Keagamaan.
} 
Tsanawiyah di Jawa dan di luar Jawa. ${ }^{8}$ Puslitbang Lektur dan Khazanah Keagamaan juga pernah melakukan penelitian tentang literatur keagamaan di perguruan tinggi umum pada tahun 2006 dan 2007, sebagaimana misalnya ditampilkan oleh Akbar ${ }^{9}$ dan Saefullah. ${ }^{10}$

Bagaimana dengan literatur keagamaan atau bacaan keagamaan di sekolah umum? Tampaknya kajian yang terakhir ini belum banyak dilakukan. Jika pun ada, pendekatannya masih merupakan pendekatan kajian teks, seperti yang pernah dilakukan oleh Balai Litbang Agama Jakarta, yang meneliti buku teks Pendidikan Agama Islam di SMA yang digunakan di berbagai daerah, ${ }^{11}$ dan Riza Ul-Haq dkk., yang meneliti aspek-aspek multikulturalisme dalam buku Al-Islam untuk tingkat SLTA Muhammadiyah. ${ }^{12}$ Kajian-kajian yang memeriksa literatur keagamaan yang lebih menitikberatkan pada selera pembacatidak sekadar pada kajian teks, apalagi dalam konteks pendidikan di sekolah umum belum banyak dilakukan. Padahal, ini penting dilakukan untuk melihat model bacaan keagamaan yang digemari siswa. Sehingga pada akhirnya nanti dapat dibuat satu rencana strategis desain literatur/bacaan keagamaan dalam konteks penguatan pendidikan agama di sekolah

${ }^{8}$ Tim Puslitbang Lektur. 2009. Puslitbang Lektur Keagamaan dari Masa ke Masa. Jakarta: Puslitbang Lektur dan Khazanah Keagamaan, h. 101-102.

${ }^{9}$ Ali Akbar. 2007. "Berjuang di Jalan Dakwah: Kajian Pemetaan Buku-Buku Keagamaan di Universitas Negeri Yogyakarta." Jurnal Lektur Keagamaan, Vol. 5 No. 1.

${ }^{10}$ Asep Saefullah. 2008. "Peta Lektur Keagamaan pada Kelompok Keagamaan di IPB: Benang Merah Gerakan Islam Asasi." Jurnal Lektur Keagamaan, Vol. 6 No. 1.

${ }^{11}$ Tim Peneliti Balai Litbang Agama Jakarta. 2011. Buku Teks Pendidikan Agama Islam sebagai Media Belajar. Jakarta: Balai Litbang Agama Jakarta.

${ }^{12}$ Fajar Riza Ul-Haq. 2007. Studi Muatan Buku Teks Al-Islam untuk Tingkat SLTA Muhammadiyah. Jakarta: Ma'arif Institute. umum. Secara sistematis penelitian dalam tulisan ini mengajukan dua pertanyaan: (1) bagaimana pembacaan siswa terhadap bacaan keagamaan? (2) bagaimana bacaan keagamaan tersebut berafiliasi dengan peta pemikiran Islam yang berkembang saat ini? Pertanyaan kedua diajukan oleh peneliti adalah sebagai evaluasi kritis terhadap bacaan-bacaan keagamaan yang dibaca oleh siswa.

Agar lebih fokus, penelitian ini menentukan satu komunitas atau organisasi tertentu dalam sekolah. Kelompok yang memang fokus dengan kegiatan keagamaan di sekolah umum biasanya disebut dengan organisasi ekstrakurikuler Rohani Islam (Rohis). Mengapa hanya Rohis? Berdasarkan hasil penelitian Lembaga Kajian Islam dan Perdamaian (LaKIP) di tahun 2010 2011, yang menemukan bahwa adanya kecenderungan persetujuan pesan-pesan 'radikalisme' dan 'kekerasan' di kalangan siswa-siswa di organisasi ekstra keagamaan di sekolah, semisal organisasi Rohis. ${ }^{13}$ Kemudian, penelitian yang dilakukan oleh Farha Ciciek sebagaimana yang juga dikutip dalam laporan kehidupan beragama CRCS Universitas Gadjah Mada pada tahun 2008, menemukan bahwa dalam kegiatan Rohis atau dalam masing-masing aktivitas individu, cenderung mengembangkan pandangan dan sikap yang eksklusif yang merupakan cerminan dari kelompokkelompok Islam tertentu sehingga banyak menarik siswa pada sikap 'radikalisme' agama. $^{14}$

${ }^{13}$ Sarlito Wirawan Sarwono. 2011. Terorisme di Indonesia dalam Tinjauan Psikologi. Jakarta: Alvabet, h. 87.

14 Zainal Abidin Bagir, dkk. 2008. Laporan Tahunan Kehidupan Beragama di Indonesia Tahun 2008. Yogyakarta: Program Studi Agama dan Lintas Budaya, Center for Religious and Cross Cultural Studies (CRCS) UGM, h. 27. 


\section{Kerangka Teori}

Penelitian ini menggunakan teori resepsi teks. Resepsi teks diartikan sebagai penerimaan pembaca terhadap teks. Beberapa sumber menggunakan istilah 'studi khalayak' atau 'studi audiens'. ${ }^{15}$ Studi khalayak atau studi audiens kemudian banyak dikembangkan dalam kerangka studi media komunikasi dan kajian budaya (cultural studies). ${ }^{16}$ Pada dasarnya istilah 'resepsi' bermula dari sebuah teori sastra yang menekankan pada analisis pembaca karya sastra, yaitu tanggapan yang bersifat penafsiran dan penilaian terhadap karya sastra yang terbit dalam rentang waktu tertentu. ${ }^{17}$

Teori resepsi sastra ini kemudian diadopsi dalam teori komunikasi. Analisis dengan teori resepsi biasanya masuk dalam pembahasan studi audiens/ khalayak/pembaca, yang termasuk di dalamnya motivasi audiens/pembaca dalam memilih/menerima pesan media/ buku. ${ }^{18}$ Morley sebagaimana dikutip oleh Adi, ${ }^{19}$ berdasarkan kategori encoding/ decoding-nya Stuart Hall (sumber pesan/ penerima pesan) mengemukakan tiga posisi pembaca teks (media/program) kemungkinan menanggapi sebuah pesan: (1) Dominant ('hegemonic') reading : pembaca sejalan dengan kode-kode program (yang didalamnya terkandung nilai-nilai, sikap,

\footnotetext{
${ }^{15}$ Jane Stokes. 2006. How to Do Media and Cultural Studies: Panduan untuk Melaksanakan Penelitian dalam Kajian Media dan Budaya. Terj. Santi Indra Astuti. Yogyakarta: Bentang.

${ }^{16}$ Chris Barker. 2009. Cultural Studies. Cet. Ke-9. Terj. Nurhadi. Yogyakarta: Kreasi Wacana, h. 34

17 Panuti Sudjiman. 1990. Kamus Istilah Sastra. Jakarta: UI Press, h. 78;

${ }^{18}$ John Vivian. 2008. Teori Komunikasi Massa. Jakarta: Prenada Kencana, h. 438.

19 Tri Nugroho Adi. 2012. "Mengkaji Khalayak Media dengan Metode Penelitian Resepsi," dalam Acta diurnA, Vol. 8 No.1.
}

keyakinan dan asumsi) dan secara penuh menerima makna yang disodorkan dan dikehendaki oleh si pembuat program; (2) Negotiated reading : pembaca dalam batasbatas tertentu sejalan dengan kode-kode program dan pada dasarnya menerima makna yang disodorkan oleh si pembuat program namun memodifikasikannya sedemikian rupa sehingga mencerminkan posisi dan minat-minat pribadinya; (3) Oppositional ('counter hegemonic') reading: pembaca tidak sejalan dengan kodekode program dan menolak makna atau pembacaan yang disodorkan, dan kemudian menentukan frame alternatif sendiri di dalam menginterpretasikan pesan/ program. Dalam perspektif Vandevelde ada pembacaan yang sifatnya negosiasi dan navigasi (mengarahkan). ${ }^{20}$

\section{METODOLOGI PENELITIAN}

Tulisan ini menyajikan hasil penelitian tentang resepsi dan afiliasi bacaan siswa aktivis Rohani Islam (ROHIS) di Sekolah Menengah Atas Negeri (SMAN). Penelitian dilakukan di Kota Serang, Banten. Kota Serang dijadikan wilayah penelitian disebabkan selain sebagai ibu kota Propinsi Banten, dikenal sebagai kota yang religius, juga untuk mencoba melengkapi hasil penelitian Ciciek dkk. yang menjadikan Pandeglang (salah satu kabupaten di Propinsi Banten) sebagai wilayah sasaran penelitian. ${ }^{21}$ Sayangnya, Ciciek tidak memberikan alasan secara rinci mengenai alasan pemilihan Kabupaten Pandeglang sebagai sasaran penelitian dalam laporan hasil penelitiannya. Selain itu juga, ia tidak

\footnotetext{
${ }^{20}$ Pol Vandevelde. 2005. The Task of the Interpreter: Text, Meaning, and Negotiation. Pittsburgh: University of Pittsburgh.

${ }^{21}$ Farha Ciciek dkk. 2008. "Laporan Penelitian: Kaum Muda dan "Regenerasi" Gerakan Fundamentalis di Indonesia (Studi tentang Unit Kerohanian Islam di SMU Negeri)." Jakarta: Rahima.
} 
memerinci sekolah mana yang dijadikan sasaran penelitian.

Penelitian ini mengambil kasus tiga Sekolah Menengah Atas Negeri (SMAN), yakni SMAN 1 Kota Serang, SMAN 2 Kota Serang, dan SMAN 4 Kota Serang. Tiga sekolah ini dipilih karena, berdasarkan informasi yang dihimpun dari studi awal, cukup aktif kegiatan keagamaanya. Tiga sekolah ini juga dipandang dapat menjadi contoh bagi kondisi sosio-kultural lokasi sekolah di mana berada. Pengumpulan data dilakukan melalui serangkaian wawancara dengan beberapa informan yang dipandang langsung terkait dengan kegiatan keagamaan, terutama siswa/siswi pengurus/ aktivis ROHIS dan para pembinanya. Untuk melengkapi data hasil wawancara dilakukan pula observasi dan studi teks. Studi teks diperlukan untuk menelaah isi dari bacaan yang diresepsi oleh siswa/siswi.

\section{HASIL DAN PEMBAHASAN}

\section{Setting Penelitian}

Sekolah Menengah Atas Negeri (SMAN) 1 letaknya di tengah kota, dan sudah sejak dahulu telah menjadi sekolah favorit. SMAN 1 berdiri pada 1954. Karena letaknya di tengah kota, latar belakang ekonomi orang tua siswa-siswanya adalah kelas menengah ke atas. Orang tua mereka termasuk kaum profesional terdidik, seperti pejabat pemerintahan, guru, dan pengusaha. Meskipun disebut sebagai sekolah umum dan tidak ada aturan sekolah untuk mewajibkan-yang ada hanya anjuran dari guru-bagi siswi muslimah untuk memakai kerudung dan rok panjang serta baju lengan panjang (pakaian muslimah), tetapi rata-rata siswinya menggunakan kerudung dan menggunakan rok panjang serta baju berlengan panjang. Bagi siswi yang tidak menggunakan kerudung, mereka berpakaian rok panjang dengan baju lengan pendek. Tidak ada siswi yang menggunakan rok pendek, meskipun non-muslim. Dalam pembelajaran Pendidikan Agama Islam (PAI), siswa dan siswi non-muslim dipersilahkan untuk memilih apakah akan tetap di kelas untuk mengikuti pelajaran atau mempelajari agamanya sendiri.

Organisasi ekstra keagamaan di SMAN 1 Kota Serang dinamakan/disingkat dengan RISMANSA (Remaja Islam Musholla AlHidayah SMAN 1 Kota Serang). Hal ini menunjukkan bahwa kegiatan keagamaan dipusatkan di musala, yang juga menjadi milik sekolah. Ada hal yang menarik di balik didirikannya musala ini. Menurut salah seorang informan yang juga sebagai Pembina RISMANSA, musala didirikan karena kasus 3 tahun sebelumnya. Sebelumnya kegiatan keagamaan RISMANSA dilakukan di musala di luar lingkungan sekolah. Meskipun letaknya dekat dengan sekolah, para pembina (yang terdiri dari guru agama sekolah) mengakui sering tidak mengetahui dan tidak bisa mengontrol secara maksimal terhadap kegiatankegiatan keagamaan yang dilakukan, sehingga terkadang terdapat materi-materi yang menurut pandangan pembina (guru agama) tidak sesuai dengan ajaran "Islam pada umumnya." Para informan (pembina/ guru agama) mengakui, bahwa sebelum kegiatan di pusatkan di musala sekolah, beberapa kasus yang mengemuka sering terkait dengan beberapa organisasi, seperti NII (Negara Islam Indonesia) dan HTI (Hizbut Tahrir Indonesia). Saat ini, hal tersebut tidak berlaku lagi, sebab semua kegiatan keagamaan RISMANSA selalu dilakukan di musala sekolah atau di aula/ruangan lainnya di dalam lingkungan sekolah dan langsung didampingi oleh pembina/guru agama sekolah. Selain itu, jika ada permintaan "mentoring" (pembimbingan) dari luar pihak sekolah, maka pembina/guru agama sekolah melakukan seleksi. 
Kegiatan keagamaan RISMANSA meliputi ta'lim (pembelajaran) ilmu-ilmu agama, seperti akidah, fikih, dan akhlak yang dilakukan secara bersama-sama baik ikhwan (anggota RISMA laki-laki) maupun akhwat (anggota RISMA perempuan). Ada juga kegiatan yang khusus dilaksanakan oleh akhwat, namun diikuti oleh seluruh siswi sekolah, yakni kegiatan keputrian. Keputrian dilakukan pada hari Jumat, ketika para siswa melaksanakan salat Jumat berjamaah. Keputrian diisi dengan berbagai macam kegiatan yang bersifat tematik. Misalnya: (1) kajian mingguan dengan tematema: "saudariku, apa yang menghalangimu untuk berhijab?"; "ukhuwah Islamiyah"; "bolehkah akhwat bernasyid?"; "dahsyatnya keutamaan membaca al-Qur'an”, (2) Rujak Party yang dilakukan setiap bulan dengan tema-tema: "mengenal kekasih yang tampan dan agung," "wanita tiang negara?," (3) "nonton bareng dan bermanfaat."

Adapun kegiatan-kegiatan yang dilakukan bersamaan dalam satu waktu antara $i k h w a n$ dan akhwat adalah pemberian motivasi dan Malam Bina Iman dan Takwa (MABIT). Pada kegiatan pemberian motivasi, yang lebih diberikan adalah motivasi belajar dan beribadah, serta berakhlak yang baik. Sedangkan dalam kegiatan MABIT, yang lebih ditekankan adalah pembinaan ritual ibadah dan akhlak, yang dilakukan dengan salat malam berjamaah, membaca ayat-ayat al-Qur'an, tausiyah (ceramah agama), dan muhasabah al-nafs (introspeksi diri) yang dipandu oleh para pembina dan guru agama. Menurut seorang informan, semua kegiatankegiatan tersebut dipandu dan didampingi oleh guru agama.

Meskipun letaknya di Jl. SerangPandeglang, latar belakang siswa-siswa SMAN 2 Kota Serang (berdiri pada 1982) hampir sama dengan SMAN 1, bahkan menurut salah seorang informan (kepala sekolah), anak-anak pejabat pemerintahan lebih banyak memilih menyekolahkan anaknya ke SMAN 2, dan tentu saja selain mereka banyak yang juga ingin masuk ke sekolah ini oleh karena, bersama-sama dengan SMAN 1, SMAN 2 juga menjadi sekolah favorit bahkan menjadi "saingan." Suasana religius dan disiplin tampak selalu diterapkan dalam sekolah. Ketika saya memasuki pintu masuk sekolah, di sebuah bangunan yang ditempati guru piket, terdapat beberapa layar monitor yang terhubung dengan kamera CCTV untuk memantau aktivitas siswa di ruang kelas, baik pada saat kegiatan pembelajaran maupun tidak. Salah seorang pembina ROHIS dan kepala sekolah ini mengakui, dengan cara seperti itu, siswa-siswi jadi terbiasa berperilaku dan berkata yang baik di lingkungan sekolah, meskipun tidak dapat memastikan jika di luar sekolah.

Kepala sekolah dan para pembina ROHIS juga mengakui berbagai prestasi yang banyak diraih sekolah, itu disebabkan karena landasan nilai-nilai agama siswa-siswi yang selalu diasah. Bentuknya melalui apa yang mereka sebut sebagai "pembiasaan." Maksudnya adalah setiap minggu di hari Rabu dan Jumat, pada pagi hari sebelum kegiatan belajar-mengajar, seluruh siswasiswi dikumpulkan di halaman sekolah bersama serta seluruh guru. Hal yang dilakukan adalah semacam muhasabah alnafs (introspeksi diri), pertobatan dan doa bersama. Kepala sekolah juga mengakui bahwa karena aktivitas "pembiasan" ini dan dampaknya bagi prestasi siswa, ia banyak diundang berbagai sekolah untuk berbagi pengalamannya. Mereka juga mewajibkan bagi siswa-siswi yang Muslim untuk salat berjamaah zuhur dan asar di masjid sekolah. Kepala sekolah berpandangan bahwa semua guru di sekolahnya adalah "guru agama," karena semua guru mata pelajaran masing-masing wajib mengajarkan dan mencontohkan nilai-nilai agama yang dianut. 
Beberapa kegiatan keagamaan yang dilakukan oleh ROHIS SMAN 2 Kota Serang adalah MABIT (malam bina iman dan takwa), yakni suatu kegiatan yang dilakukan pada malam hari yang diisi dengan kegiatankegiatan ibadah dan mentoring. Dalam mentoring (suatu kegiatan penyampaian materi dakwah di mana siswa berkumpul dengan duduk melingkar, kemudian disampaikan materi oleh seorang pemateri), setiap siswa mencatat materi-materi dalam sebuah buku yang kemudian ditanda tangani oleh para pembina ROHIS. Meskipun dilakukan kegiatan mentoring yang terkadang para pemateri diambil dari luar sekolah seperti alumni, namun pembina ROHIS mengatakan semuanya dalam keadaan terkontrol dan terseleksi, sehingga tidak terjadi pemberian materi-materi yang di luar konteks pembinaan akhlak dan bersifat politis.

Adapun SMAN 4 Kota Serang terletak di Jalan Raya Banten KM. 5 Kecamatan Kasemen, arah menuju situs Banten Lama. Oleh karena itu letaknya dapat dikatakan di pinggiran Kota Serang. Berdiri pada tahun 2000. Latar belakang siswanya pun berbeda dengan SMAN 1 dan SMAN 2 Serang. Tidak hanya latar belakang sosial-ekonominya yang berbeda, dalam hal kegiatan-kegiatan keagamaannya pun agak berbeda. Kegiatan mentoring tidak dilakukan dan MABIT dihilangkan. Menurut pembina ROHISnya, hal ini untuk mengontrol kegiatan keagamaan, pasalnya hal itu tidak sesuai dengan latar belakang sosial-keagamaan siswa-siswanya yang lebih menyukai pengajian kitab kuning, selain itu juga hal ini menghindari terulangnya penyusupan materi-materi tertentu yang tidak sesuai dengan ajaran Islam yang diajarkan di sekolah. Seorang pembina ROHIS mengatakan bahwa ia dipilih oleh pimpinan sekolah untuk menggantikan pembina ROHIS sebelumnya disebabkan di antaranya karena disinyalir terkait dengan organisasi HTI.

Kegiatan-kegiatan dalam ROHIS di antaranya pengajian Jumat, yang diisi dengan pembacaan Surat Yasin dan kuliah tujuh menit (Kultum) serta pengajianpengajian kitab-kitab, seperti kitab Safinat al-Najah. Selebihnya kegiatan-kegiatan lebih diisi pembelajaran baca al-Quran dan tajwidnya. Hal ini, menurut sang pembina, sangat berbeda dengan materi-materi yang diberikan oleh pembina sebelumnya. Dalam rangkaian salah satu kegiatan pesantren kilat di tahun 2008 yang dibuat oleh pembina sebelumnya, memang terdapat materi yang terperinci mengenai akidah, ibadah dan akhlak. Semua rujukan mengacu pada alQuran atau hadis, jarang merujuk pada kitabkitab yang biasa dirujuk kalangan pesantren. Namun, ada rujukan terhadap salah satu tokoh dalam pemikiran Islam, yakni Ibnu Taymiyah, seperti ketika menjelaskan mengenai konsekuensi iman, dijelaskan bahwa menurut Ibnu Taymiyah Ilah (Tuhan) adalah "sesuatu yang dicondongi oleh hati dengan dicintai, ditakuti, diharapkan dan sejenisnya, dan segala sesuatu yang diibadati selain Allah adalah thogut." Dalam rangkaian penjelasan akidah, ibadah, dan akhlak semua dijelaskan dalam terang oposisi biner: muslim dan kafir.

Hal ini berbeda dengan panduan kegiatan pesantren kilat di tahun 2012, yang disusun oleh pembina ROHIS saat penelitian dilakukan. Panduan yang dibuat lebih merupakan tuntunan ritual peribadatan dengan tidak membuat bingkai oposisi sebagaimana yang dilakukan oleh pembina ROHIS sebelumnya. Yang berbeda dari SMAN 1 dan 2, siswa-siswa yang bersekolah di SMAN 4 ini, terlebih-lebih yang mengikuti kegiatan ROHIS, sering mengikuti pengajianpengajian kitab kuning di luar sekolah, bahkan beberapa di antara aktivis ROHIS menjadi santri di sebuah pesantren tertentu yang ada di sekitar wilayah sekolah. 


\section{Literatur Keagamaan: Resepsi Siswa}

Kebanyakan para pembina ROHIS atau guru-guru agama di sekolah yang saya teliti tidakpernahtahu,ataumencobamenanyakan kepada siswa-siswanya perihal kesenangan siswa terhadap bacaan tertentu. Padahal ini penting untuk melihat kecenderungan minat dan pikiran siswa tentang sebuah isu tertentu, bahkan jika terkait dengan isu-isu keagamaan. Para pembina dan guru agama kebanyakan mengakui hal tersebut. Memang ketika ditanyakan mengenai buku-buku atau rujukan yang digunakan untuk mengisi materi, para pembina dan guru agama sering hanya menjawab bukubuku yang berisi ajaran-ajaran Islam "arus utama" (mainstream), seperti terjemahan alQuran yang diterbitkan oleh Kementerian Agama, kitab hadis Bulugh al-Maram (kitab hadis tentang hukum-hukum fikih karya Ibn Hajr al-Asqalani), Sahih al-Bukhari, dan tafsir Al-Misbah karya M. Quraish Shihab, serta kitab Safinat al-Najah (kitab karya Salim bin Samir al-Hadrami tentang akidah dan fikih). Beberapa guru juga melengkapi materi dengan mengunduh dari internet.

Berikut beberapa buku/bacaan yang berhasil dihimpun melalui wawancara dengan pengurus ROHIS di tiga sekolah:

Tabel 1

Judul-judul Bacaan/Buku yang Dibaca Siswa/Siswi ROHIS

\begin{tabular}{|l|l|l|l|}
\hline No & Judul Buku & \multicolumn{1}{|c|}{ Penulis } & \multicolumn{1}{c|}{ Keterangan } \\
\hline 1 & $\begin{array}{l}\text { Udah } \\
\text { Putusin Aja! }\end{array}$ & $\begin{array}{l}\text { Karya Felix } \\
\text { Siauw }\end{array}$ & $\begin{array}{l}\text { Tentang larangan } \\
\text { pacaran. }\end{array}$ \\
\hline 2 & $\begin{array}{l}\text { La Tahzan for } \\
\text { Girls, agar } \\
\text { Kamu Para } \\
\text { Cewek tidak } \\
\text { Takut Hadapi } \\
\text { Masa Depan }\end{array}$ & Najla Mahfuzh & $\begin{array}{l}\text { Tentang motivasi } \\
\text { untuk percaya diri } \\
\text { bagi para remaja } \\
\text { putri Islam. }\end{array}$ \\
\hline 3 & $\begin{array}{l}\text { Kado Cinta } \\
\text { untuk } \\
\text { Remaja }\end{array}$ & $\begin{array}{l}\text { Harlis } \\
\text { Kurniawan }\end{array}$ & $\begin{array}{l}\text { Mengenai berbagai } \\
\text { hikmah kehidupan } \\
\text { yang dikemas } \\
\text { dengan bahasa } \\
\text { anak muda. }\end{array}$ \\
\hline
\end{tabular}

\begin{tabular}{|c|c|c|c|}
\hline No & Judul Buku & Penulis & Keterangan \\
\hline 4 & $\begin{array}{l}\text { Negeri } 5 \\
\text { Menara }\end{array}$ & A. Fuadi & $\begin{array}{l}\text { Novel mengenai } \\
\text { kisah perjalanan } \\
\text { menggapai cita- } \\
\text { cita dari seorang } \\
\text { tokoh santri. }\end{array}$ \\
\hline 5 & Yuk Berhijab! & Felix Y. Siauw & $\begin{array}{l}\text { Mengenai } \\
\text { penjelasan- } \\
\text { penjelasan tentang } \\
\text { penting dan } \\
\text { wajibnya berhijab. }\end{array}$ \\
\hline 6 & $\begin{array}{l}\text { Dialah Sang } \\
\text { Ratu }\end{array}$ & $\begin{array}{l}\text { Muhammad } \\
\text { Al-Areifi }\end{array}$ & $\begin{array}{l}\text { Buku ini mencerita- } \\
\text { kan tentang } \\
\text { keteguhan seorang } \\
\text { wanita modern } \\
\text { dalam memelihara } \\
\text { kodratnya sebagai } \\
\text { seorang wanita di } \\
\text { tengah isu gender. }\end{array}$ \\
\hline 7 & $\begin{array}{l}\text { If I Should } \\
\text { Speak: Novel } \\
\text { Catatan } \\
\text { Nurani } \\
\text { Mualaf } \\
\text { Amerika }\end{array}$ & Ummu Zakiyah & $\begin{array}{l}\text { Novel yang } \\
\text { menceritakan } \\
\text { pengalaman- } \\
\text { pengalaman } \\
\text { memasuki agama } \\
\text { Islam oleh seorang } \\
\text { muallaf di Amerika. }\end{array}$ \\
\hline 8 & $\begin{array}{l}\text { Bisikan dari } \\
\text { Langit }\end{array}$ & G. Lutfiyanto & $\begin{array}{l}\text { Kumpulan kisah } \\
\text { Islami remaja yang } \\
\text { memberi pesan } \\
\text { mengenai betapa } \\
\text { maha kuasanya } \\
\text { Allah. }\end{array}$ \\
\hline 9 & $\begin{array}{l}\text { Ranah } 3 \\
\text { Warna }\end{array}$ & A. Fuadi & $\begin{array}{l}\text { Lanjutan dari novel } \\
\text { "Negeri } 5 \text { Menara" } \\
\text { yang menceritakan } \\
\text { kisah pencarian } \\
\text { cita-cita seorang } \\
\text { santri. }\end{array}$ \\
\hline 10 & $\begin{array}{l}\text { Ayat-ayat } \\
\text { Cinta }\end{array}$ & $\begin{array}{l}\text { Habiburrahman } \\
\text { el-Shirazi }\end{array}$ & $\begin{array}{l}\text { Novel percintaan } \\
\text { "Islami" berlatar } \\
\text { belakang Negeri } \\
\text { Mesir, yang dibalut } \\
\text { dengan "pesan- } \\
\text { pesan dakwah" } \\
\text { lainnya. }\end{array}$ \\
\hline 11 & $\begin{array}{l}\text { Kantorku } \\
\text { Surgaku }\end{array}$ & $\begin{array}{l}\text { Nanang } \\
\text { Mubarok }\end{array}$ & $\begin{array}{l}\text { Sebuah buku } \\
\text { motovasi mengenai } \\
\text { manajemen waktu } \\
\text { untuk beraktivitas } \\
\text { dan beribadah. }\end{array}$ \\
\hline 12 & $\begin{array}{l}\text { Majalah Al- } \\
\text { Hidayah }\end{array}$ & & $\begin{array}{l}\text { Sebuah majalah } \\
\text { religius dengan } \\
\text { berbagai rubrik, } \\
\text { dan yang paling } \\
\text { muncul adalah } \\
\text { rubrik kisah nyata } \\
\text { dengan cerita yang } \\
\text { agak misteri. }\end{array}$ \\
\hline 13 & $\begin{array}{l}\text { Majalah } \\
\text { Qiblati }\end{array}$ & & $\begin{array}{l}\text { Majalah Islam } \\
\text { berhaluan salafi. }\end{array}$ \\
\hline 14 & $\begin{array}{l}\text { Akhlaq li al- } \\
\text { Banin }\end{array}$ & $\begin{array}{l}\text { Syaikh Umar } \\
\text { Baraja }\end{array}$ & Mengenai akhlak. \\
\hline
\end{tabular}




\begin{tabular}{|l|l|l|l|}
\hline No & Judul Buku & \multicolumn{1}{|c|}{ Penulis } & \multicolumn{1}{c|}{ Keterangan } \\
\hline 15 & $\begin{array}{l}\text { Safinat al- } \\
\text { Naja }>\mathrm{h}\end{array}$ & $\begin{array}{l}\text { Salim bin } \\
\text { Sami }>\mathrm{r} \text { al- } \\
\text { Hadra }>\mathrm{mi}\end{array}$ & $\begin{array}{l}\text { Mengenai akidah } \\
\text { dan fikih. }\end{array}$ \\
\hline
\end{tabular}

Baik siswa-siswa di SMAN 1, SMAN 2, dan SMAN 4 yang menjadi pengurus di organisasi RISMANSA dan ROHIS, mereka tetap membaca buku yang menjadi pegangan dalam pembelajaran Pendidikan Agama Islam (PAI), tetapi sekadar untuk memenuhi kebutuhan belajar di sekolah. Mereka lebih memilih bacaan-bacaan alternatif sebagaimana tampak dalam tabel di atas, bahkan ada yang tetap setia dengan bacaan-bacaan yang dipelajari di pesantrenpesantren.

Penting dicatat, kebanyakan pengurus ROHIS memang sudah bisa membaca alQuran, jadi ketika ditanya buku agama apa yang sering dibaca, mereka kebanyakan menjawab membaca al-Quran dan terjemahannya. Hal ini terutama sangat tampak pada siswa (ikhwan), meskipun ada beberapa siswa yang menjawab dengan jelas bacaan apa yang digemari, seperti salah satu ikhwan pengurus RISMANSA yang mengaku membaca buku "Kantorku Surgaku", dan salah satu ikhwan pengurus ROHIS SMAN 4 mengaku membaca kitab Akhlaq li alBanin dan Safinat al-Najah, bahkan ada yang rutin membaca Dalail al-Khairat, sebuah kitab karangan Sulaiman al-Jazuli, yang populer dibacakan di kalangan pesantren. Keterikatan pada dunia pesantren ini juga tampak dalam pengakuan salah seorang aktivis ROHIS SMAN 4, bahwa ia mengagumi Syaikh Nawawi al-Bantani dengan alasan "bisa menciptakan dan mengarang kitab gundul."

Para pengurus ROHIS akhwat lebih banyak menyukai bacaan-bacaan seputar wanita dan teks-teks bergenre novel. Hal yang menarik, baik di SMAN 1 maupun SMAN 2, ada dua buku dengan satu penulis yang sama, yakni Felix Y Siauw. Dua bukunya yang dibaca oleh beberapa akhwat adalah Yuk Berhijab! dan Udah Putusin Aja! Kedua buku ini diakui sangat menganjurkan untuk memahami "Islam lebih dalam lagi." Seorang aktivis akhwat mengaku dengan membaca buku Udah Putusin Aja! ia sadar bahwa betapa rugi mempunyai pacar. Sedangkan seorang akhwat yang lain mengaku buku tersebut mengajarkan bagaimana remaja Islam "berpacaran." Adapun untuk buku Yuk Berhijab! ditanggapi sama, yakni buku tersebut memotivasi muslimah untuk berhijab dan memberikan pengetahuan tentang pakaian muslimah yang seharusnya digunakan sesuai syariat.

Selain soal ketertarikan substansi, ada hal lain yang menjadikan akhwat ROHIS/ RISMANSA ini tertarik membaca kedua buku karangan Felix Siauw tersebut. Mereka berpendapat bahwa gaya penulisan Felix sangat mudah dicerna. "Kata-katanya tidak monoton, seru, menarik, dan pastinya banyak banget manfaatnya," salah seorang akhwat RISMANSA berpendapat mengenai dua buku Felix. Tidak jelas benar mana yang lebih dahulu, apakah soal substansi terlebih dahulu yang mendorong mereka untuk membaca kedua buku karya Felix, atau lebih tertarik dengan "gaya bukunya," atau keduaduanya sekaligus yang mendorong mereka membaca. Tetapi yang penting dicatat, mereka membaca kedua buku tersebut didahului oleh pengetahuan tentang akan pentingnya busana muslimah untuk menutup aurat dan akhlak hubungan antara remaja putra dan putri dalam Islam, sesuatu yang menurut para pembimbing dan guru agama sering disampaikan dalam kegiatan keagamaan maupun dalam pembelajaran agama di kelas.

Bukan hanya pada kedua buku Felix, beberapa buku dibaca juga dengan alasan "bahasanya mudah dimengerti dan ceritanya seru." Hal ini misalnya ketika seorang 
akhwat pengurus di RISMANSA membaca buku Bisikan dari Langit karya G. Lutfianto. Buku tersebut adalah sebuah buku kumpulan cerita pendek (cerpen) remaja Islami, yang berbentuk "fiksi ilmiah." Judul Bisikan dari Langit sendiri adalah salah satu judul cerita pendek yang termasuk kumpulan cerpen tersebut. Ceritanya mengenai kiamat karena bumi dihantam asteroid. Ceritacerita pendek yang ada dalam buku ini semuanya berujung untuk meningkatkan keimanan, karena semuanya bermuara pada pengakuan kemahakuasaan Allah SWT. Oleh karenanya, kumpulan cerpen dalam buku ini juga dapat dilihat sebagai cerita-cerita mengenai keimanan.

Cerita pergumulan iman juga tampak pada novel If I Should Speak, karya Ummu Zakiyyah. Salah seorang akhwat pengurus RISMANSA dan ROHIS SMAN 2 mengaku bahwa novel tersebut menjelaskan tentang Islam dilihat dari sudut pandang agama lain. "Tapi penulis juga menjelaskan bantahan dari sudut pandang yang logis, dan ada hadis-hadisnya juga," demikian salah seorang akhwat berpendapat. If I should speak adalah sebuah novel yang bercerita tentang pencarian iman seorang mahasiswi di Amerika, sehingga akhirnya ia masuk ke dalam agama Islam.

Alasan "motivasi" juga tampak ketika beberapa akhwat dalam pengurus RISMANSA dan ROHIS SMA 2 berpendapat bahwa bukubuku novel seperti Negeri 5 Menara dan Ranah 3 Warna memberikan motivasi mengejar cita-cita. Salah seorang akhwat berujar: "novelnya sangat inspiratif dan motivatif terutama untuk pelajar, yang dalam meraih mimpinya tidak terlepas dari doa dan ikhtiar."

Resepsi ikhwan dan akhwat dalam RISMANSA (SMAN 1) dan ROHIS (SMAN 2 dan 4) terhadap bacaan keagamaan dapat juga dilihat dari beberapa pengarang yang menjadi favorit, seperti Asma Nadia dan Habiburrahman el-Shirazy, dan tidak ketinggalan Felix Siauw. Asma Nadia adalah-bersama-sama dengan Helfy Tiana Rosa-salah seorang pendiri dan pengurusForumLingkar Pena (sebuah forum penulis/calon penulis yang berdiri pada 1997 dengan tujuan menjadi wadah pembelajaran para penulis muda). Ia adalah penulis novel, cerpen dan esai yang seringkali bernafaskan Islami. Tidak kurang dari 26 karyanya telah diterbitkan, baik dalam bentuk novel, kumpulan cerita pendek maupun esaiesai, yang ditulis sendiri maupun secara kolaboratif. Asma Nadia, menurut salah seorang akhwat ROHIS di SMA 2, "di dalam bukunya selalu menceritakan realitas kehidupan masyarakat, mengajarkan kita untuk belajar dan memahami Islam lebih dalam lagi."

Habiburrahman el-Shirazy menjadi populer sebagai penulis sejak novelnya, Ayat-Ayat Cinta, diterbitkan. Sejak itu AyatAyat Cinta dicetak ulang, dan sejak itu pula "novel-novel cinta" karyanya bermunculan. Ada kira-kira 9 buku yang sudah diterbitkan, semuanya bergenre novel.

Adapun Felix Siauw, yang kedua bukunya sudah disinggung di atas, adalah seorang yang berlatar belakang pendakwah dan aktivis. Selain kedua buku yang sudah disebut di atas, tiga buku lainnya juga sudah diterbitkan, yakni: Muhammad Al-Fatih 1453, Beyond the Inspiration, How to Master Your Habits.

Muhammad Al-Fatih 1453 adalah kisah tentang salah satu pertempuran paling penting dalam sejarah Islam dan sejarah dunia, yakni pertempuran Byzantium dan Utsmani. Beyond the Inspiration memberikan argumen-argumen kemulian Islam yang menginspirasi dan memotivasi umatnya untuk berjaya. Singkatnya, buku-buku tersebut memberikan argumen bahwa jika umat Islam ingin kembali merebut kejayaan, maka disarankan Islam harus dijadikan 
sumber kehidupan yang menyeluruh (kafah). Sedangkan buku How to Master Your Habits sebetulnya menjelaskan bagaimana membiasakan "cara hidup Islami" dalam sistem kehidupan manusia. Buku-buku karya Felix Siauw tersebut, termasuk Yuk Berhijab! dan Udah Putusin Aja! adalah dapat dikatakan buku-buku yang memberikan haluan kepada Muslim dan Muslimah untuk menjalankan ajaran Islam secara menyeluruh dalam seluruh sistem kehidupan mereka (kafah).

Jadi, jika dilihat dari uraian di atas, setidaknya ada tiga resepsi siswa terkait dengan bacaan/teks keagamaan yang dibacanya. Resepsi tersebut bisa dalam bentuk penilaian atau alasan dalam membaca sebuah teks. Ketiga resepsi tersebut adalah terkait dengan substansi yang memotivasi, gaya bahasa, dan "kedekatan kultural." Dua yang pertama sudah jelas dalam uraian, hanya saja yang perlu ditambahkan maksud motivasi di sini bisa dalam artian motivasi dalam meraih cita-cita atau motivasi memperkuat keimanan atau ajaran agama. Sedangkan terkait dengan "kedekatan kultural," maksudnya adalah dalam pemilihan bacaan tertentu, orang terkadang mengaitkan dengan wawasan dan teks-teks yang pernah dipelajarinya atau yang pernah diketahuinya. Contohnya yang paling mudah adalah beberapa ikhwan/ siswa yang berasal dan tumbuh dalam budaya pesantren (sebagaimana di SMAN 4), cenderung memilih bacaan-bacaan yang pernah dikenalnya dalam lingkungan budayanya, seperti ia jelas sangat mencintai kitab kuning yang dipelajarinya dan sudah menjadi epistemologi pesantren (bagian dari sistem pengetahuan pesantren). ${ }^{22}$

${ }^{22}$ Ahmad Baso. 2012. Pesantren Studies 2b. Buku II: Kosmopolitanisme Peradaban Kaum Santri di Masa Kolonial. Juz Kedua: Sastra Pesantren dan Jejaring TeksTeks Aswaja-Keindonesiaan dari Wali Songo ke Abad 19. Tangerang Selatan: Pustaka Afid.
Penting dicatat bahwa ada beberapa bacaan yang dibaca karena motivasi dan gaya bahasa sekaligus. Misalnya beberapa akhwat membaca buku Yuk Berhijab! itu selain gaya bahasanya yang mudah dicerna, juga adanya motivasi untuk memakai pakaian muslimah yang sesuai ajaran Islam.

Sampai di sini, maka dalam resepsi bacaan ini kadang terjadi negotiate deading, ${ }^{23}$ yakni pembaca dalam batas-batas tertentu sejalan dengan dan menerima makna yang disodorkan oleh si penulis, namun memodifikasikannya sedemikian rupa sehingga mencerminkan posisi dan minat-minat pribadinya. Dalam konsepsi Vandevelde, ${ }^{24}$ pembacaan negosiasi terjadi dalam hal "the literal meaning of words and the composed sentences" (makna literal kata-kata dan susunan kalimat). Dari sinilah, mungkin, dapat dijelaskan mengenai pertanyaan mengapa banyak siswa yang terkadang tidak tertarik dengan buku-buku pelajaran PAI yang menjadi sumber belajar sebagaimana disarankan oleh guru di sekolah. Bisa saja siswa/siswi cenderung bosan dengan gaya bahasa dan gaya tampilan bukunya.

\section{Literatur Keagamaan: Pesan dan Afiliasi}

Hasil pembacaan negosiatif terkadang dapat menerima pesan utama sebuah teks, dan terkadang juga tidak, tergantung pada negosiasi macam apa yang dilakukan: apakah negosiasi maksud pengarang dan pesan utama sebuah teks, atau negosiasi gaya bahasa teks. Pada bagian sebelumnya, sudah dijelaskan bahwa negosiasi yang terjadi adalah negosiasi tujuan dan gaya bahasa teks. Karenanya, kadang-kadang

${ }^{23}$ Tri Nugroho Adi. 2012. "Mengkaji Khalayak Media dengan Metode Penelitian Resepsi," dalam Acta diurnA, Vol. 8 No.1.

${ }^{24}$ Pol Vandevelde. 2005. The Task of the Interpreter: Text, Meaning, and Negotiation. Pittsburgh: University of Pittsburgh, h. 219. 
orang luput memperhatikan pesan utama sebuah teks, yang sesungguhnya pesan itu dibungkus dengan gaya tertentu sehingga tanpa disadari pesan diterima. Itu artinya dibutuhkan pemeriksaan terhadap isi atau pesan utama dari teks yang dibaca.

Karena keterbatasan tempat, dalam tulisan ini tidak semua buku dibahas, tetapi hanya mengambil satu contoh. Pembahasan difokuskan pada pesan utama dan afiliasi teks. Ini dengan asumsi bahwa-sebagaimana dalam perspektif intertekstuaitas ${ }^{25}$-sebuah teks sering kali terkait dengan teks-teks lainnya baik yang menjadi rujukan maupun turunan. Saya memfokuskan pada dua buku karya satu penulis, yakni Felix Siauw. Argumennya adalah, sebagaimana yang sudah dipaparkan di atas, baik di RISMANSA maupun ROHIS SMAN 2, aktivis yang menjadi informan penelitian ini menaruh perhatian terhadap buku-buku Siauw.

Pertama, soal isi/pesan teks dari karyanya. Saya memulai dari Yuk Berhijab! Buku ini pada intinya memberikan pesan kepada pembaca untuk memakai "hijab." Yang dimaksud "hijab" menurut buku ini adalah gabungan pakaian rumah, kerudung, dan jilbab ("baju kurung"). ${ }^{26}$ Ia membedakan antara kewajiban menutup aurat dalam salat bagi muslimah dengan kewajiban memakai pakaian yang "sesuai syariah" selain menutup aurat.Pendapat ini sama dengan kebanyakan ulama fikih. Bahkan, Siauw sendiri mengakui beberapa perbedaan tafsir mengenai yang dimaksud dengan jilbab. Ia menyebutkan bahwa beberapa pendapat itu adalah setidaknya ada lima, yakni pendapat Ibn Katsir, Imam Al-Qurtubi, Ibn Rajab, Al-Biqa'i, dan Ibn Manzur dalam Lisan al-'Arab. Namun, ia berpendapat

${ }^{25}$ Graham Allen. 2000. Intertextuality. London: Routledge.

${ }^{26}$ Felix Siauw. 2013. Yuk Berhijab!. Bandung: Mizania, h. 64. bahwa meskipun berbeda-beda dalam memberikan pengertian tentang "jilbab", namun kesimpulannya sama, yakni seorang wanita muslim wajib memakai pakaian syar'i penutup aurat (hijab), yakni pakaian rumah (al-tsaub), yang dirangkapkan jilbab (baju kurung) di atasnya, serta dilengkapi dengan khimar (penutup kepala, leher hingga dadanya). ${ }^{27}$

Memang Siauw juga mengutip dua ayat yang sering dijadikan rujukan dalam hal kewajiban menutup aurat bagi muslimah ini, yakni surat Al-Nur (24) ayat 31 dan surat Al-Ahzab (33) ayat 59, namun ia kurang mengeksplorasi soal perbedaan tafsir mengenai maksud "pengecualian" dalam surat Al-Nur (24) ayat $31^{28}$ sebagaimana yang diuraikan oleh Shihab misalnya. ${ }^{29}$ Ia mengajukan setidaknya ada tiga pendapat mengenai tafsir kata-kata "kecuali yang tampak darinya." Titik persoalannya ada pada kata "illa" dalam bahasa Arab, yang terjemah bahasa Indonesianya berarti "kecuali."

\footnotetext{
${ }^{27}$ Ibid, h. 81.
}

${ }^{28}$ Terjemahan ayat tersebut adalah: Katakanlah, kepada wanita yang beriman, hendaklah mereka menahan pandangannya, dan memelihara kemaluannya dan janganlah mereka menampakkan perhiasannya kecuali yang tampak darinya. Hendaklah mereka mengulurkan/menutupkan kain kudung ke dadanya dan janganlah menampakkan perhiasannya, kecuali kepada suami mereka, atau ayah mereka, atau mertua mereka, atau putraputra mereka, atau putra-putra suami mereka, atau saudara lelaki mereka, atau putra-putra saudara lelaki mereka, atau putra-putra saudara perempuan mereka, atau wanita-wanita Islam, atau budak-budak yang mereka miliki, atau pelayan-pelayan lelaki yang tidak mempunyai keinginan terhadap wanita, atau anak-anak yang belum mengerti tentang aurat wanita. Janganlah mereka memukulkan kakinya agar diketahui perhiasan yang mereka sembunyikan dan bertobatlah kamu sekalian kepada Allah, hai orang yang beriman, supaya kamu beruntung.

${ }^{29}$ M. Quraish Shihab. 1996. Wawasan Al-Qur'an: Tafsir Maudhu'i atas Pelbagai Persoalan Umat. Bandung: Mizan, h. 170-178. 
Pertama, pendapat yang mengajukan bahwa kata "illa" yang dimaksud adalah bukan termasuk yang disebut sebelumnya (dalam istilah gramatika bahasa Arab disebut itstitsna munqati. Jadi ayat tersebut dapat dipahami dengan: "Janganlah mereka menampakkan hiasan mereka sama sekali; tetapi apa yang tampak (secara terpaksa/ bukan sengaja)." Kedua, pendapat yang mencoba menyisipkan kalimat dalam penggalan ayat tersebut, yang kemudian memberikan pesan: "Janganlah mereka (wanita-wanita) menampakkan hiasan (badan mereka). Mereka berdosa jika demikian. Tetapi jika tampak tanpa disengaja, maka mereka tidak berdosa." Kedua pendapat ini sebetulnya sama, yakni sama "membolehkan" menampakan "hiasan" mereka jika tanpa disengaja. Adapaun pendapat yang ketiga adalah memberikan pemahaman bahwa "kecuali apa yang tampak" dalam arti yang biasa dan atau dibutuhkan keterbukaannya sehingga harus tampak.

Menurut Shihab,30 pendapat ketiga ini adalah pendapat yang dipegangi oleh mayoritas ulama. Setelah mengutip berbagai pendapat mengenai hal-hal yang terkait dengan batasan "apa yang tampak" atau "yang biasa dan atau dibutuhkan keterbukaannya," seperti Al-Qurtubi dan ahli hukum Abu Yusuf, serta beberapa hadis yang diriwayatkan oleh al-Tabari, Abu Dawud, Ibn 'Abbas, Ibn Qatadah, Shihab menyimpulkan bahwa sesuatu yang dikecualikan itu berkembang sesuai dengan kebutuhan yang dialami seseorang dan kebiasaan yang berlaku. Bahkan, ketika mengutip pendapat ulama kontemporer, seperti Muhammad Tahir bin Asyur yang berpendapat bahwa "cara memakai jilbab berbeda-beda sesuai dengan perbedaan keadaan wanita dan adat mereka. Tetapi tujuan perintah ini adalah

\footnotetext{
${ }^{30} \mathrm{Ibid}, \mathrm{h} .174$
}

seperti bunyi ayat itu yakni: agar mereka dapat dikenal (sebagai wanita Muslim yang baik) sehingga tidak digangu". ${ }^{31}$

Uraian soal berbagai pendapat di atas, sebetulnya ingin mengatakan bahwa ada hal yang kurang dijelaskan oleh Siauw dalam bukunya. Namun, tentu saja hal ini dapat dipahami jika melihat tujuan buku ini, yang tampaknya untuk memudahkan dan menghindari hal-hal yang bersifat polemik, sehingga pesan utama yang ingin disampaikan mudah dicerna. Jadi sebetulnya, buku Yuk Berhijab! dan Udah Putusin Aja! (untuk buku ini saya tidak banyak membahasnya karena isinya juga tidak banyak yang bersifat polemik, bahkan tidak terdapat daftar pustaka sebagaimana buku pertama) adalah buku-buku yang ditulis sebagai panduan yang harus diikuti oleh pembacanya. Hal ini tampak jelas dalam salah satu pendapatnya, bahwa "Islam tidak hanya berbicara dalam tataran konseptual". ${ }^{32}$ Oleh karena itu, tentu saja tujuan utama dari buku ini tentu saja adalah isi pesannya yang siap dipraktikkan.

Mengapa Siauw mengatakan bahwa Islam tidak hanya berbicara dalam tataran konseptual? Memang, sebelum banyak menjelaskan soal kewajiban menutup aurat dengan hijab, ia menyampaikan tentang konsep wanita dalam Islam. Menurutnya,Islam memuliakan dan memanusiakan manusia dengan fitrahnya masing-masing. Islam memandang lakilaki dan wanita sama harkatnya di hadapan Allah, hanya mereka yang takwa yang tinggi harkatnya di hadapan Allah, namun pada saat yang sama, Islam juga membedakan fitrah laki-laki dan wanita. Ia mencontohkan, jika laki-laki memperoleh pahala tertinggi dengan jihad di jalan Allah, maka wanita

${ }^{31}$ Ibid, h. 177.

32 Felix Siauw. 2013. Yuk Berhijab!. Bandung: Mizania, h. 44. 
memperoleh pahala dari melahirkan anakanaknya, atau melaksanakan umrah dan haji. ${ }^{33}$

Gaya buku Yuk Berhijab! dan Udah Putusin Aja! berbeda dengan buku-bukunya yang lain, seperti dalam Beyond the Inspiration dan Muhammad Al-Fatih 1453. Dalam Beyond the Inspiration misalnya, gaya bahasa yang disajikan tidak sebebas dalam kedua bukunya di atas, pembahasannya pun cenderung pada konsep polemik seperti khilafah. ${ }^{34}$ Sehingga, dapat dipahami bila beberapa informan penelitian ini tidak ada yang membaca buku tersebut. Namun, menurut saya, buku Beyond the Inspiration penting artinya untuk melihat afiliasi dan orientasi keagamaan penulisnya.

Kedua, pembahasan soal afiliasi teks tidak sekadar melacak dan menghubunghubungkan teks-teks yang dirujuk, tetapi juga menelaah sistematika berpikir penulis, dan menelaah sistematika berpikir-dalam konteks penelitian ini-dapat dilihat dalam sistematika teks yang ditulisnya. Memang, langkah termudah adalah mengaitkan dengan tokoh atau teks yang dirujuknya. ${ }^{35}$

Salah satu tokoh yang dirujuk Siauw dalam Yuk Berhijab!, Beyond the Inspiration, dan How to Master Your Habits adalah Taqiyuddin al-Nabhani. Ia adalah pendiri Hizb al-Tahrir (HT), yakni sebuah gerakan politik Islam transnasional untuk menegakkan syariah Islam melalui khilafah

\footnotetext{
${ }^{33}$ Ibid, h. 35.

${ }^{34}$ Ibid, h. 262-263.

${ }^{35}$ Dalam hal ini bedakan antara fungsi rujukan dalam karya-karya yang sifatnya akademis-ilmiah dengan karya-karya yang sifat "propagandis" atau "ideologis." Pengertian yang kedua adalah yang dimaksud dalam penelitian ini.
}

Islamiyah. ${ }^{36}$ Bahkan, buku al-Nabhani yang dirujuk oleh Siauw dalam Yuk Berhijab! dan Beyond the Inspiration adalah buku yang menjadi "babon" dari gerakan HT bahkan untuk Hizbut Tahrir Indonesia (HTI), yakni Nizam al-Islam (biasa diterjemahkan dengan "Sistem/Peraturan Hidup Islami" atau "The System of Islam").

Al-Nabhani, ${ }^{37}$ dalam buku tersebut berpandangan bahwa ideologi di dunia ini ada tiga, yakni kapitalisme, sosialisme/ komunisme, dan Islam. Ideologi Islam dengan penerapan sistem Islami dalam sejarahnya hanya pernah dijalankan sejak masa Nabi Muhammad SAW berada di Madinah hingga tahun 1918 M, yakni ketika jatuhnya negara Islam yang terakhir ke tangan penjajah.Yang dimaksud dengan jatuhnya negara (dawlah) Islam terakhir ke tangan penjajah mungkin adalah Turki Usmani (Turki Ottoman). ${ }^{38}$

Al-Nabhani yang kemudian diyakini oleh kalangan HT dan HTI, berpandangan bahwa ideologi (mabda') dan pemikiran (fikrah) Islam tidak bertentangan dengan fitrah kemanusiaan dan mudah dimengerti. Ideologi komunis bertentangan dengan fitrah manusia oleh karena ideologi tersebut menafikan kecenderungan manusia untuk beragama. Sebaliknya ideologi komunis selalu hanya menekankan ketiadaan Tuhan

${ }^{36}$ Di Indonesia, HT menjadi gerakan organisasi sosial-masyarkaat (Ormas) menjadi Hizbut Tahrir Indonesia (HTI). Lihat Ainur Rofiq Al-Amin. 2012. Membongkar Proyek Khilafah ala Hizbut Tahrir Indonesia. Yogyakarta: LkiS, h. 22; Haedar Nashir. 2013. Islam Syariat: Reproduksi Salafiyah Ideologis di Indonesia. Bandung: Mizan, h. 403.

${ }^{37}$ Al-Nabhani, Taqiyuddin. 2006. Peraturan Hidup dalam Islam. Jakarta: HTI Press, h. 56; Ainur Rofiq AlAmin. 2012. Membongkar Proyek Khilafah ala Hizbut Tahrir Indonesia, h. 24.

${ }^{38}$ John L. Esposito. 2010. Islam Straight Path: Ragam Ekspresi Menuju Jalan Lurus. Jakarta: Paramadina dan Dian Rakyat, h. 91; Karen Armstrong. 2002. Islam: A Short History. New York: The Modern Library Chronicles Book, The Modern Libabry, h. xxx. 
dan spiritualitas. Ideologi kapitalismesekularismejuga bertentangan denganfitrah manusia. Meskipun ideologi kapitalismesekularisme tetap mengakui adanya agama, namun ideologi ini tetap memisahkan agama dengan kehidupan. Agama hanya dijalankan secara individu dan tidak diatur sebagai sebuah sistem kehidupan manusia. Kelemahan ideologi kapitalismesekularisme, dan selanjutnya demokrasi tampak selalu tidak sempurnanya dalam melahirkanaturan, sedangkan ideologi Islam yang-menurut Al-Nabhani-sesuai dengan fitrah manusia itu sempurna dalam melahirkan aturan.

Oleh karena itu, kalangan HT meyakini bahwa semua isme-isme yang dilahirkan oleh manusia tidak sesuai dengan fitrah manusia, sehingga ia sudah memiliki "cacat bawaan," bahkan menjadi hal yang diharamkan dalam doktrin Islam itu sendiri. Kaum muslim juga diharamkan mendirikan partai politik berdasarkan ideologi-ideologi buatan manusia tersebut, dan haram menjadi anggotanya atau partisipannya, karena partai-partai seperti itu termasuk partai-partai kufur dan mengajak pada kekufuran.

Kalangan HT meyakini bahwa akidah Islam merupakan pemikiran yang bersfifat politik dan dasar bagi pemikiran politik bagi umat Islam. Karena itu, umat Islam harus sadar politik. ${ }^{39}$ Berdasarkan hal itu dapat dipahami bahwa seluruh aktivitas HT bersifat politis, yaitu dengan jalan mengatur dan memperhatikan urusan masyarakat sesuai dengan hukum dan pemecahan syariat Islam, yang merupakan bagian sangat penting bagi dakwah Islam untuk mengubah masyarakat yang rusak menjadi masyarakat Islam. ${ }^{40}$

\footnotetext{
${ }^{39}$ Ainur Rofiq Al-Amin. Op.cit, h. 23.

${ }^{40}$ Haedar Nashir, Op.cit, h. 407.
}

Bagian awal buku Yuk Berhijab! tampak menunjukkan pandangan yang sama dengan al-Nabhani ini, terutama pandangan mengenai segala ide-ide di luar Islam itu menyalahi fitrah Islam. Mula-mula ditunjukkan kelemahan-kelemahan tradisitradisi dan pandangan-pandangan dunia di luar Islam, lalu menunjukkan keunggulan pandangan Islam atas semua pandangan dunia yang pernah ada. Siauw menunjukkan bagaimana dunia memandang wanita. Ia berpendapat bahwa dalam tradisi-tradisi non-Islam, wanita selalu di pandang rendah. Ia menyebut peradaban Yunani Kuno membolehkan wanita diperjualbelikan layaknya budak, tidak memiliki hak sipil dan juga hak waris. Dalam peradaban Yunani Kuno, wanita sekadar pemuas nafsu bagi laki-laki. Hal yang sama juga berlaku dalam peradaban Romawi, yang masih dipengaruhi peradaban Yunani. Bahkan, menurutnya,dalam peradaban Romawi, seorang laki-laki tidak bersalah jika membunuh istri dan anaknya bila tidak suka dengan perbuatan istri dan anaknya. Apapun yang didapatkan wanita di rumah tangga, tidak ada hak untuk protes dan meminta pisah. Lebih-lebih dalam tradisi Hindu, yang kenal dengan Sati, yakni sebuah prosesi membakar diri bagi janda yang ditinggal mati suaminya. Saat suaminya meninggal dan dibakar, maka berakhir juga hak hidup sang istri. Di Cina pun demikian, wanita tetap dipandang sebagai kelas dua. Singkatnya, Siauw berpendapat bahwa peradabanperadaban non-Islam, bahkan agama-agama non-Islam, seperti yang ditunjukkan dalam tafsir dari teks-teks kitab suci mereka serta pendapat-pendapat agamawan pada agama Yahudi dan Nasrani selalu berujung pada diskriminasi wanita.

Ide-ide emansipasi, kesetaraan gender maupun feminisme juga mendapat kritik dari Siauw. Menurutnya, harapan wanita agar sama dengan laki-laki dalam segala 
hal, bukannya berahasil memuliakan wanita, tetapi menjadi penghancuran martabat wanita sendiri, karena menjauh dan mengingkari fitrah wanita itu sendiri. Terlebih dengan adanya paham sekulerisme, posisi wanita semakin tersungkur karena sistem yang menghalalkan cara apapun untuk dijual demi asas manfaat, eksploitasi tubuh wanita menjadi bisnis yang menghasilkan dengan modal yang hemat.

Hal yang sama juga ditunjukkan dalam Beyond the Inspiration. Menurut Siauw dalam buku ini, kehancuran dan keterpurukan umat Islam itu terjadi ketikaIslam sebagai pandangan hidup ditinggalkan oleh kaum Muslim sendiri, yang disebabkan karena silau dengan kebangkitan semu dunia Barat. Menurutnya, pada suatu masa dulu, Islam diingat sebagai suatu peradaban yang terbesar dan terhebat, memberi kontribusi yang tidak terhitung banyaknya dalam bidang sains dan kesejahteraan umat manusia. Islam di kala itu bukan hanya sebagai agama, tetapi inspirasi agung yang meninggalkan sejarah dunia yang gemilang. Namun saat ini, hal itu menghilang bahkan umat Muslim menjadi pesakitan dan terpuruk dalam berbagai bidang kehidupan serta hingga mereka lupa dengan jati diri mereka.

Siauw juga menunjukkan cacatnya hukum yang dibuat manusia yang dapat dilihat dalam dua hal: pertama, aturan yang dibuat manusia selalu menyebabkan hancurnya tatanan hidup di segala bidang. Dalam bidang politik misalnya, lahir tatanan politik imperial, eksploitasi bangsa-bangsa dan perbudakan atas umat manusia. Dalam aspek sosial terjadi seks bebas dan aborsi. Dalam bidang ekonomi, sistem kapitalisme buatan manusia telah menyebabkan sebagaian besar penduduk dunia miskin. Kedua, tatanan hidup buatan manusia itu menyebabkan kerusakan alam, yang semuanya itu disebabkan oleh pengelolaan alam cara sistem kapitalisme buatan manusia yang menyalahi fitrah manusia. Walaupun telah nyata-nyata menunjukkan kerusakan dan ketidaksesuaian dengan kehidupan manusia, namun tetap saja sistem buatan manusia ini dipakai dan diterapkan, yang seharusnya dicari alternatif aturan lain yang mampu mengakomodasi seluruh ketimpangan manusia dan alam semesta.

Jadi, jika diperhatikan pandanganpandangan Siauw dalam buku-bukunya, setidaknya dalam dua bukunya yang dideskripsikan di atas, sama atau setidaknya memiliki keterkaitan dengan ide-ide alNabhani mengenai kesempurnaan sistem Islam yang mampu memberikan solusi atas tatanan dunia yang terpuruk. Hal tersebut disebabkan ideologi Islam sesuai dengan fitrah manusia, yakni selalu mencari kepada agama yang menyelamatkan dirinya. Memang, bagi al-Nabhani dan eksponen HT dan HTI penerapan sistem Islam secara menyeluruh adalah manifestasi keimanan dan terealiasi dalam kewajiban memilih pemimpin, yaitu khalifah dan bai'at. ${ }^{41}$ Oleh karena itu, dapat dipahami di dalam beberapa buku Siauw, terutama Beyond the Inspiration, How to Master Your Habits serta Muhammad Al-Fatih 1453, ide-ide dan konsepkonsep khilafah, serta ide-ide yang terkait dengannya seperti penerapan syariat Islam, selalu disinggung. Misalnya dalam How to Master Your Habits, Siauw bahkan menampilkan satu teks bahasa Arab tentang konsep khilafah yang bertujuan hanya untuk memberikan contoh mengenai kebiasaan (habit) membaca teks Arab.

\section{PENUTUP}

\section{Kesimpulan}

Siswa-siswa di SMAN 1, SMAN 2, dan SMAN 4 yang menjadi pengurus di organisasi

\footnotetext{
${ }^{41}$ Ibid, h. 405.
} 
ROHIS, tetap membaca buku yang menjadi pegangan dalam pembelajaran Pendidikan Agama Islam (PAI), tetapi sekadar untuk memenuhi kebutuhan belajar di kelas sekolah. Mereka lebih memilih bacaanbacaan alternatif, bahkan ada yang tetap setia dengan bacaan-bacaan yang dipelajari di pesantren-pesantren. Hal yang terkahir ini berlaku di SMAN 4.

Beberapa literatur yang diminati siswasiswi aktivis dapat berupa buku bacaan motivasi pembinaan akhlak atau novel. Aktivis akhwat lebih suka membaca bukubuku bergenre novel dan teks-teks yang terkait dengan wanita. Setidaknya ada tiga alasan yang mendorong para aktivis memilih sebuah bacaan untuk dibaca, yakni alasan substansi yang memotivasi, gaya, dan kedekatan kultural. Seringkali alasan gaya ini lebih sering muncul ketimbang substansi. Maka dapat dipahami, banyak aktivis yang lebih menyukai buku-buku yang ringan untuk dibaca, daripada buku-buku teks pembelajaran PAI yang berat. Dalam konteks ini, pembacaan negosiasi dalam hal gaya bahasa terjadi.

Negosiasi dalam gaya bahasa dapat menuntun untuk memahami mengapa buku-buku dengan satu penulis tertentu disenangi, setidaknya di dua SMAN (SMAN 1 dan SMAN 2), yakni: dua buku karya Felix Siauw, Yuk Berhijab! dan Udah Putusin Aja! Mereka berpendapat bahwa gaya penulisan Siauw sangat mudah dicerna.

Adapun terkait dengan "kedekatan kultural," maksudnya adalah dalam pemilihan bacaan tertentu, siswa cenderung memilih bacaan-bacaan yang pernah dikenalnya dalam lingkungan budayanya, seperti kitab kuning yang dipelajarinya di pesantren. Hal ini jelas mengapa beberapa siswa aktivis ROHIS SMAN 4 lebih senang membaca kitab-kitab pesantren yang dipelajari, bahkan tokoh-tokoh penulis yang disenanginyapun sudah menjadi populer di kalangan pesantren.

Jika diperhatikan, kebanyakan bukubuku yang dibaca adalah buku-buku yang memberikan pesan keagamaan, baik dalam buku yang sifatnya fiksi maupun non-fiksi. Buku-buku tersebut ada yang berafiliasi dengan wawasan Islam Moderat (ini yang lebih banyak), tetapi ada juga yang tidak. Namun, yang menarik perhatian adalah, sebagaimana dikemukakan di atas, salah satu penulis yang bukunya banyak mendapat perhatian dari para aktivis ROHIS adalah Felix Siauw, seorang penulis dan tokoh yang memikiki afiliasi dengan gagasan khilafah Islamiah.

Telaah ini menggiring kesimpulan bahwa sebetulnya pesan yang ingin disampaikan Siauw melalui buku-bukunya, termasuk dua buku yang banyak dibaca oleh kalangan aktivis ROHIS adalah perbaikan akhlak, yakni akhlak menjaga aurat bagi wanita dan akhlak dalam berhubungan laki-laki dengan wanita. Tetapi, harus diakui juga bahwa buku-buku Siauw banyak dipengaruhi oleh ide-ide al-Nabhani yang merupakan tokoh dan ideolog HT dan HTI. Ada kesamaan antara ide-ide Islam alNabhani dengan sistematika berpikir Siauw sebagaimana tampak dalam buku-bukunya.

\section{Saran}

Perlu dipikirkan dan dijalankan sebuah strategi penghadiran buku agama, yang mungkin sesuai dengan pandangan Islam arus utama (mainstream) di Indonesia, sesuai dengan karakter dan jatidiri bangsa, yang dari sisi pembaca remaja (termasuk para aktivis ROHIS) dapat diterima dan menyenangkan karena gayanya yang 'segar', sehingga pesan yang ingin disampaikan dapat sampai kepada pembaca. Dengan adanya pembacaan negosiasi, penulis buku atau guru agama serta pemangku kebijakan 
pendidikan agama Islam (Kementerian Agama), perlu lebih cermat memperhatikan minat bacaan keagamaan siswa, karena sebagaimana hasil penelitian yang telah dikemukakan di atas, siswa-dalam hal ini aktivis ROHIS-cenderung memilih bacaan alternatif yang tidak atau belum diberikan di kelas secara formal, bahkan terkadang guru dan pembimbing pun tidak tahu apa yang dibaca oleh siswa.

\section{DAFTAR PUSTAKA}

Adi, Tri Nugroho. (2012): "Mengkaji Khalayak Media dengan Metode Penelitian Resepsi," dalam Acta diurnA, Vol. 8 No.1.

Akbar, Ali. (2007): "Berjuang di Jalan Dakwah: Kajian Pemetaan Buku-Buku Keagamaan di Universitas Negeri Yogyakarta." Jurnal Lektur Keagamaan, Vol. 5 No. 1.

Al-Amin, Ainur Rofiq. (2012): Membongkar Proyek Khilafah ala Hizbut Tahrir Indonesia. Yogyakarta, LKiS.

Allen, Graham. (2000):. Intertextuality. London, Routledge.

Armstrong, Karen. (2002): Islam: A Short History. New York: The Modern Library Chronicles Book, The Modern Libaray.

Bagir, Zainal Abidin, dkk. (2008): Laporan Tahunan Kehidupan Beragama di Indonesia Tahun 2008. Yogyakarta, Program Studi Agama dan Lintas Budaya, Center for Religious and Cross Cultural Studies (CRCS) UGM.

Barker, Chris. (2009): Cultural Studies. Cet. Ke-9. Terj. Nurhadi. Yogyakarta, Kreasi Wacana.
Baso, Ahmad. (2012): Pesantren Studies $2 b$. Buku II: Kosmopolitanisme Peradaban Kaum Santri di Masa Kolonial. Juz Kedua: Sastra Pesantren dan Jejaring Teks-Teks Aswaja-Keindonesiaan dari Wali Songo ke Abad 19. Tangerang Selatan, Pustaka Afid.

Basri, Husen Hasan, dkk. (2011): Pengajaran Kitab Kuning di Pondok Pesantren. Jakarta, Puslitbang Pendidikan Agama dan Keagamaan.

Bruinessen, Martin van. (1990): “Kitab Kuning; Books in Arabic script used in the Pesantren milieu; Comments on a new collection in the KITLV Library." Bijdragen tot de Taal-, Land-en Volkenkunde 146 (2/3).

Ciciek, Farha dkk. (2008): "Laporan Penelitian: Kaum Muda dan "Regenerasi" Gerakan Fundamentalis di Indonesia (Studi tentang Unit Kerohanian Islam di SMU Negeri). Jakarta, Rahima.

El Fadl, Khaled Abou. (2006): Selamatkan Islam dari Muslim Puritan. Jakarta, PT. Serambi Ilmu Semesta.

Esposito, John L. (2010): Islam Straight Path: Ragam Ekspresi Menuju Jalan Lurus. Jakarta, Paramadina dan Dian Rakyat.

Al-Nabhani, Taqiyuddin (2006): Peraturan Hidup dalam Islam. Jakarta: HTI Press.

Nashir, Haedar (2013): Islam Syariat: Reproduksi Salafiyah Ideologis di Indonesia. Bandung, Mizan.

Saefullah, Asep (2008): "Peta Lektur Keagamaan pada Kelompok Keagamaan di IPB: Benang Merah Gerakan Islam Asasi." Jurnal Lektur Keagamaan, Vol. 6 No. 1.

Sarwono, Sarlito Wirawan (2011): Terorisme di Indonesia dalam Tinjauan Psikologi. Jakarta, Alvabet.

Shihab, M. Quraish (1996): Wawasan AlQur'an: Tafsir Maudhu'i atas Pelbagai Persoalan Umat. Bandung, Mizan. 
Siauw, Felix. (2013): Yuk Berhijab!. Bandung, Mizania.

(2013): Beyond the Inspiration. Jakarta, Alfatih Press. . (2013): How to Master Your Habits. Jakarta, Alfatih Press.

Stokes, Jane (2006): How to Do Media and Cultural Studies: Panduan untuk Melaksanakan Penelitian dalam Kajian Media dan Budaya. Terj. Santi Indra Astuti. Yogyakarta, Bentang.

Sudjiman, Panuti (ed). (1990): Kamus Istilah Sastra. Jakarta, UI Press.

Syatibi, M, Badri Yunardi, dkk. (2006): Pergeseran Literatur di Pondok Pesantren Salafiyah di Indonesia. Jakarta, Puslitbang Lektur Keagamaan.

Tim Peneliti Balai Litbang Agama Jakarta (2011): Buku Teks Pendidikan Agama Islam sebagai Media Belajar. Jakarta: Balai Litbang Agama Jakarta.

Tim Puslitbang Lektur (2009): Puslitbang Lektur Keagamaan dari Masa ke Masa. Jakarta: Puslitbang Lektur dan Khazanah Keagamaan.
Ul-Haq, Fajar Riza. (2007): Studi Muatan Buku Teks Al-Islam untuk Tingkat SLTA Muhammadiyah. Jakarta, Ma'arif Institute.

Vandevelde, Pol. (2005): The Task of the Interpreter: Text, Meaning, and Negotiation. Pittsburgh, University of Pittsburgh.

Vivian, John. (2008): Teori Komunikasi Massa. Jakarta, Prenada Kencana.

Voort, Van der, Nicolet Boekhoef, Kees Versteegh dan Joas Wagemakers. (2011): "Introduction." Dalam The Transmission and Dynamics of the Textual Sources of Islam. Ed. Van der Voort, Nicolet Boekhoef, Kees Versteegh dan Joas Wagemakers. Leiden and Boston: Brill.

Weber, Max. (2001): The Protestant Ethic and the Spirit of Capitalism. Terbit pertama kali 1930. Diterjemahkan oleh Talcott Parsons. London: Routledge Classics.

Zaidan, Abdul Razak, Anita K Rustapa, Hani'ah. (2004): Kamus Istilah Sastra. Jakarta, Balai Pustaka. 